\title{
Mit kao tema i referentno opće mjesto u posttridentskom književnom tekstu. Interpretatio slavica antičkog mita i soteriološki mit u Vili Slovinki Jurja Barakovića
}

Divna Mrdeža Antonina (Zadar)

\begin{abstract}
Sažetak
Izlaganje se osvrće na funkciju i status mitoloških tema i figura u spjevu Vila Slovinka (1614) Jurja Barakovića. Spjev posjeduje određeni sloj motivike i figuralnosti antičke mitološke provenijencije u mjeri koja je bila široko rasprostranjena u književnosti ranoga novog vijeka kao svojevrsna humanistička legitimacija obrazovana pisca i kad piše na vernakularu. Posttridentski utjecaj na spjev odražava se u žanrovskim i tematskim obilježjima drugoga dijela spjeva, koja čine otklon u odnosu na prvi njegov dio zamišljen i napisan prvotno kao samostalna cjelina, a posttridentski duh regulira i (ne)prisutnost mitskih tema, motiva i popularnih figura. Budući da su mitološka motivika, tematika i figuracija svojevrstan odraz autorova obrazovnog, a kršćanska njegova svjetonazornog habitusa, zanimljivo je kontekstualizirati napor uložen u koegzistenciju humanističkog i posttridentskog kao dvaju obrazaca u djelu.
\end{abstract}

\section{Ključne riječi}

Juraj Baraković; Vila Slovinka; mit u književnosti; humanizam; posttridentsko razdoblje

\begin{abstract}
Myth as a Topic and a Commonplace in the Post-Tridentine Literary Text. Interpretatio Slavica of the Antique Myth and Soteriological Myth in Vila Slovinka by Juraj Baraković

This paper reflects upon function and status of mythological topics and figures in the poem Vila Slovinka (1614) by Juraj Baraković. The poem in its entirety possesses a significant layer of antique figurality of mythological provenance, that was widespread in the literature of the early modern period, as a kind of humanistic legitimization of an educated writer, even whilst writing in vernacular. The post-Tridentine influences on the poem are reflected in genre and topical features of the second part of the poem, which represent a deflection in relation to its first part, originally conceived and written as a self-contained whole; and which are further reflected in interfering mythical topics and popular figures. Since mythological and Christian motifs, topics and figurations indicate both the author's educational and ideological habitus respectively, it is interesting to contextualize the effort invested in the coexistence of the humanist and the post-Tridentine, the two patterns coexisting in the poem.
\end{abstract}

\section{Key words}

Juraj Baraković; Vila Slovinka; myth in literature; humanism; Post-Tridentine Era 
Govoriti o mitu u književnosti ranoga novog vijeka podrazumijeva široko prihvaćeno stajalište o njegovu predmodernom poimanju u književnosti zapadne kulture, u koju je, kako znamo, u humanizmu renesanse s revitalizacijom antike i revalorizacijom njezinih vrijednosti uvedena i antička mitologija u sklopu novog književnog kodeksa oslonjena na antičku književnost kao neizostavnu sastavnicu u kulturnom polju, ali ne nužno i sastavnicu u humanističkom svjetonazoru, uglavnomkršćanskom. ${ }^{1} \mathrm{U}$ arhaičnim je kulturama, naime, mit označavao ,istinitu priču', a mitovi grčke i Rima ulazili su u sve novije književnosti, pa i u hrvatsku, u uobičajenom značenju vremena kao slika kulturnog pretkršćanskog svijeta koju je preoblikovao suprotstavljen joj kršćanski logos, te se mit redovito tretirao u značenju ,priče', ,invencije‘, ,fikcije‘, a ne tumačenja svijeta. Mit našeg ranog novovjekovlja ne podrazumijeva sveobuhvatnost u semantičkoj vrijednosti riječi ,mit‘ kao u današnjem znanstvenom diskurzu gdje riječ posjeduje dvoznačnu ulogu u tumačenjima mita već gotovo jedno stoljeće. ${ }^{2}$

Često se manifestira u hrvatskoj književnosti kako drevni mit postaje priča u koju se izravno intervenira humanističkom interpretacijom antičke kulture. Čitateljsku se i kazališnu publiku educira o mitskim bogovima i herojima tako da se pomoću priča o njihovim sudbinama pripovijeda o kršćanskim figurama, ili pak o sudbinama običnih ljudi ${ }^{3}$.

Kako se poganska vjera poistovjećuje s mitologijom, a injektira u nju kršćanski logos pokazuju, primjerice, figure epskih junaka. Hrvatska je epika humanizma bila sklonija biblijsko-religioznom epu poput Solimaide (Solimais, 1509) Ivana Polikarpa Severitana, De vita et gestis Christi, (1526) Jakova Bunića i Kristova smrt (De morte Christi) D. Beneše, Davidijade i, na hrvatskom jeziku, Judite Marka Marulića. ${ }^{4} \mathrm{Na}$ razini tematike, motivike i figuralnosti mit je popularan i u lirici (primjerice, u odama i epigramima Jurja Šižgorića, Janusa Panoniusa, Ilije Crijevića, Marka Marulića), gdje se pokazao otpornijim izravnim kršćanskim interpretacijama. Mitska priča kao tema pojavljuje se i u hrvatskoj tragediji (primjerice, Držićevoj Hekubi i Jokasti Miha Bunića Babulinova), a poslije tridentskog koncila dominira u libretističkoj drami (na primjer u Orfeu i Euridici Paskoja Primovića, Gundulićevoj Dijani, Prozerpini ugrabljenoj, Armidi, Alčini, Došastju od Eneje k Ankizu, ocu njegovu Junija Palmotića i djelima brojnih drugih libretista $)^{5}$. I pastoralna je drama nezamisliva kao vrsta bez mitske priče. No, mitska fikcija često je podloga ra-

1 Proces kristijanizacije mita, ali izravne, demonstrira, primjerice, već srednjovjekovni roman poput Aleksandride i Rumanca trojskog. U Aleksandridi se Aleksandar izmiješta iz povijesnog i iz antičkog mitskog konteksta te pozicionira kao figura označena proročanstvom Jeremije proroka i vjerom u Boga Sabaota.

2 ELIADE, Mircea: Mit i zbilja. Prev. Mirna Cvitan - Ljerka Mifka. Zagreb: Matica hrvatska, 1970, s. 5.

3 Ni helenski mudraci, prema mišljenju Vitomira Belaja (BELAJ, Vitomir: Hod kroz godinu. Pokušaj rekonstrukcije prahrvatskoga mitskoga svjetonazora. Zagreb: Golden marketing, 1998, s. 15), nisu podučavali publiku o bogovima, nego pomoću slika iz drevnih mitova pripovijedaju o sudbini običnih ljudi.

4 Injektiranje kršćanskog alegorijskog sloja pokazuju brojni epovi: prvi ep De raptu Cerberi (oko 1490) Jakova Bunića jer je već njegova mitološka tema pretvorena u alegorijsku kršćansku priču, budući da je figura Herkula poslužila kao cijepna podloga za figuru Krista. Nedovršeni ep De Epidauro Ilije Crijevića i Opis grada Kotora (Descriptio Asciviensis urbis) I. Bolice smještaju temu prošlosti zavičaja u mitski kontekst stare Grčke. Donekle im je u tom pogledu sličan Feretreida (Feretreis, 1522) Ivana Polikarpa Severitana, ep o povijesti obitelji Montefeltro.

5 U libretističkoj drami likovi se kršćanski svjetonazorno jasno deklariraju, ističu se kršćanskom vrlinom što obično podrazumijeva junaštvo, odanost, vjernost ili pak, nerijetko, djevičanstvo. 
zličitim alegorijskim slojevima katkad i eksplicitno prožetima kršćanskim svjetonazorom pojedinih likova. Pastoralni junak u pratnji je prijatelja, rodbine ili drugih pastira slična udesa koji ga, uglavnom uvjeravaju u nemogućnost ljubavi/opstanka u mitskom svijetu (primjerice, Radmio i Ljubmir Džore Držića, Tirena, Venere i Adon, Grižula Marina Držića).

I u drugim je pastoralnim vrstama, u prvom redu u Zoranićevim Planinama, klasična mitologija prisutna kao jedna od tema, ali u prvom redu kao njezin odjek u kojem se prema antičkim mitskim obrascima stvaraju pseudohrvatske mitske pričice da bi se omjerile snage s klasicima. ${ }^{6}$

Koegzistenciju mitskih sustava u hrvatskoj književnosti potiče pseudohistoriografija koja stare kulture i civilizacije na hrvatskim i slavenskim prostorima percipira kao povijesni kontinuitet što podrazumijeva i pretakanje kulturnih kontinuiteta. U tom segmentu se mitska (kozmogonijska i etnogenetska) i povijesna priča pojavljuju kao isprepletene, nadopunjuju se i nadovezuju jedna na drugu. Tako u psedopovijesnom kontekstu mitska priča tendira gubitku dimenzije fikcije i predstavlja se vjerodostojnom.

$\mathrm{K}$ tome, mit o postanku dio je kontigenta teološkog tumačenja svijeta koji se u naših književnika redovno i dugo vezuje uz priču o biblijskom postanku etničkih kolektiviteta. ${ }^{7}$ Vjetar u jedra širenju i dugom opstanku slavenske/hrvatske mitologije i pseudopovijesti u književnosti ${ }^{8}$ daje joj u humanizmu etablirana ideja o punopravnoj vrijednosti vernaku$\operatorname{lara}^{9} \mathrm{u}$ književnosti budući da je, mitskim jezikom tumačeno, i jezik hrvatski/slovinski nastao rasapom jezika nakon rušenja kule babilonske. Njegovo pak širenje i identificiranje s jezicima svih Slavena poduzimano je u svrhu širenja vjerskih utjecaja: protestantizma, a poglavito potom jačanja katolicizma i osnaživanja protuturskog djelovanja.

6 Naime, roman uključuje sekundarne žanrove - nove pseudohrvatske/slavenske mitske metamorfoze, pričice bašcinskoga prostora stopljene s antičkim mitskim pričama i likovima bogova, po ugledu na antičke kulture predstavljene figurama vila Latinke, Grkinje i Kaldejke ne bi li se i Vila Hrvatica imala čime pohvaliti. Do supstitucije mita nije došlo prema modelu zamjene novoga starim nego je mitska priča motivski okvir i predbašćinska historija za nove slavenizirane metamorfoze u deželji pastira Zorana/ Zoranića e da bi hrvatski/slavenski prostor dobio legitimitet sljednika antičke civilizacije preko stvorene poveznice s mitskim prostorima Grčke i Rima.

7 Mitska etnogeneza dio je nacionalne karakterologije u predmodernom razdoblju, što je čest predmet postkolonijalnih, psihosocijalnih, imagološkoh ili pak drugih kulturoloških istraživanja u novijoj znanosti o književnosti i kulturnoj povijesti. Navesti i samo izbor najrelevantnije literaturu o predmetu problem je zbog njezine opsežnosti pa ću spomenuti samo nekoliko autora utjecajnijih studija: Zrinka Blažević, Davor Dukić, Zdenka Janeković-Römer, Ivo Banac, Dean Duda, Mirko Tomasović...

8 Nalazimo je dugo u književnosti, još i u 17. i u 18. st., primjerice, kod Jeronima Kavanjina u Bogatstuu i uboštvu i u Korabljici Andrije Kačića Miošića. Inače su se „ilirskom interpretacijom“ mitskog podrijetla Hrvata i stvaranjem slovinskog/ilirskog mitskog svijeta bavili posebice uz Jurja Šižgorića i Mavra Orbinija i Pavao Ritter Vitezović te Matija Petar Katančić.

9 Zagovor vernakulara u književnosti jača već od trecenta (Dante i Cavalcanti), a rasprave su intenzivirane upravo među humanistima (A. Manuzio, G. F. Fortunio, M. Equicola, M. Palmieri), a u cinquecentu su se za tu ideju zdušno zauzimali, primjerice, Bembo, Alberti, Bandello, Manzoni, Trissino. O brojnim istraživačima koji su se bavili stvaranjem standardnog jezika u ranom novovjekovlju, pored upotrebe nadnacionalnog latinskog, opširnije u: PRICE, Glanville: Romance studies in Great Britain. In: Trends in Romance Linguistics and Philology. Vol. 4: National and Regional Trends in Romance Linguistics and Philology. Ur. Rebecca Posner i dr. The Hague - Paris - New York: Mounton Publishers, 1982, s. 146. 
Zoranićevu tematskom implementiranju geografske genealogije mitske provenijencije u hrvatskoj je književnosti osobito bliska Barakovićeva Vila Slovink ${ }^{10}$ koja dijeli s Planinama mitski motivski kompleks o podrijetlu grada, zavičaja i domovine/ jezika ${ }^{11}$ (etnogenetski i etiološki mit) kao zajednički narativni udio u viatorskom sloju priče napisane već u prvoj verziji Vile $^{12}$, a koja uglavnom obasiže prvih sedam pjevanja cjelovita spjeva u kojima se slavi Zadar. Baraković upućuje čitatelja na sličnost sa Zoranićevom pričom o podrijetlu zavičaja. ${ }^{13}$ Mit je uklopljen u sekundarni žanr radi kreiranja „povijesti“ pričom ${ }^{14}$ a „događanja“ situira konvencionalno, koristeći topologiju stvarnog geografskog prostora kao poprišta različitih mitskih događanja. Konkretno, na Kolovarima i u Zadarskom kanalu do Lukorana na Ugljanu odvija se priča o Plankiti ${ }^{15}$ i Posejdonu, o nasilnoj ljubavi iz koje će se roditi Slovan, utemeljitelj novog naroda. Konstrukt o grčko-slavenskom simboličnom rađanju Slovana (interpretatio slavica antičkoga mitskog svijeta) dopunjuje i epizoda o vjenčanju i zavjetnim darovima za sretnu budućnost djeteta gdje nastupaju i božanstva iz rimske mitologije kao uzvanici: „gdi Jove i Pala prvi broj u tancu, [...]/ pak Marte i Juno, drug druga pojima“ (Vila, 70, 95, 276-279), „Merkurij Dijanu pak malo potoli“ (Vila, 7, 95, 281). U istom društvu je i Apolon: „prid njime Apolo u poskok čitraše,/ on vile nimaše, zač srićom njegovom/ Dafne zrak skrivaše pod korom javornom." (Vila, 7, 95, 290-292). U paru dolaze Cerere i Bako (Vila, 7, 96, 315), Palada (Vila, 7, 98, 269), Mars, Vulkan, Junona, Merkur i Dijana „s parnaških gor“ kad daruju novorođenog Slovana. Bogovima se pridružuje Jazon s Argonautima koji dovršavaju gradnju Zadra (Vila,

10 „Od začetja Zadra grada“ Vila Slovinka pripovijeda u sedmom petju.

11 U Vili Slovinki vilinsko pripovjedanje postanka Zadra ima, kao i u Planinama, biblijski početak, od babilonskog rasula zbog „hude obisti nagloga Nembrota“ (Vila 7, 87, 4).

12 O prvoj verziji spjeva postoji dovoljno fakcijskih indicija implementiranih u sadržaj, a o dvama dijelovima spjeva govori se često u povijesti književnosti. Odmak od prve inačice spjeva i intervencije u tekstu vidljivi su ne samo na osnovi motivike i funkcije mitskih elemenata u slojevima priče, što usputno dodirujem i u ovom radu, nego i na metatekstualnoj, sadržajnoj i metričkoj razini. O tome već postoji i brojna literatura. Usp. npr.: ŠVELEC, Franjo: O kompozicijskim osobitostima Vile Slovinke. In: Po stazi netlačeni. Split: Čakavski sabor, 1977, s. 195-212; PETROVIĆ, Svetozar: Problem soneta u starijoj hrvatskoj književnosti (Oblik i smisao). Rad JAZU, 350, 1968, s. 5-303; PAVLIČIĆ, Pavao: Vila Slovinka. In: Epika granice. Zagreb: Matica Hrvatska, 2007, s.109-163; MRDEŽA ANTONINA, Divna: Žanrovski status teksta. In: Vila, Pisnik i čatnici. Zbornik radova sa znanstvenog skupa „Vila Slovinka' Jurja Barakovića (1614-2014)“. Ur. Divna Mrdeža Antonina. Zadar: Sveučilište u Zadru, u suradnji s HAZU i Filozofskim fakultetom u Zagrebu, 2017, s. 213-238.

13 Baraković inzistira na popravljanju „faktografije“ u Planinama pojačavajući time efekt mitskog kao povijesnog: „I Petar Zoranin imaše tu misa’ / kim opet proslu Nin, Planine kad pisa,/ ljubena pun bisa s vilami hodeći,/ u znojne dni krisa s pastiri općeći,/ Plankita hteć reći, a reče Žarka vil,/ pogodno vidjevši, tako je reći htil:/ Već nam ni rič ina neskladna neg u tom,/ dal' neka istina na mistu sidi svom." 7, 99, 433-440).

14 Baraković uvodi inačicu slovinski za imenovanje naroda koji Zoranić zove hrvatski: „pisano na sebi sam ime donese,/ u pismu tako bi, da Slovan zove se." 7, 94, 247-248), s tim da u Vili slovinsko i hrvatsko ime supostoje kao istoznačnice, ali samo je uvođenje drukčije nomenklature indikativno. Posljedica je to novog snažnog vala širenja katoličanstva na istok u što je uključena i politika jezika koja će se naročito intenzivirati poslije djelovanjem Actio de propaganda fide. O tome se u povijesti književnosti i jezika pisalo vrlo često.

15 Plankita je Ninova i Savina kćer, smještena u vrijeme grčkih božanstava kao dio istog mitološkog miljea: Dijanina je družbenica: „sama se postavi Dijanu družiti“. 7, 90, 106, a Neptun je u prvi mah, kad ju je spazio, pomislio da je jedna od Nereida: „pomisli da je vil nereida kagodi“. 
99, 425-430). Uz prožimanje kozmogonijskih mitova, grčkih i rimskih mitskih božanstava sa slavenskim mitskim bićima i vođanma iz slavenske etnogeneze, nailazimo i na ravnopravno ispreplitanje elementa iz etiološkog mita i realistične toponimije. Primjerice, kad razlaže okupljanje vila s različitih strana svijeta Vila Slovinka ravnopravno nabraja geografske i mitske prostore pa se skupa pojavljuju i Tiber i Midina rijeka Paktol, Dunav, Iber, Morava, Ksant, Ardeni, otok Del i srednjodalmatinska gora Boraja, Alpe i Apenini (Vila, 4. pjevanje).

Zbog naslijeđene je literarne konvencije, koju se upravo naglašeno apostrofira repetitivnim odnosom prema mitskoj motivici, razumljivo da su mitska i pseudopovijesna tematika redovito dio pripovijedanja mitološke pripovjedačice Vile, povijesne sveznadarke iz prve ruke, ${ }^{16}$ a manje Pisnikova, pa je razumljivo i da su njezine epizode višeslojno garnirane mitskom figuracijom, što demonstrira mnoštvo antičkih reminiscencija, asocijacija, usporedbi u iskazu na retoričkoj razini, kako se to često susreće i u književnosti klasične epike. I Pisnik, a i pjesnik, posižu za mitom kao referentnim uporištem, ali u prvom dijelu spjeva uglavnom to čini Vila. U drugom dijelu kada to radi Pisnik mijenja se i funkcija mita i reducira njegova uporaba. Antički mit kao referentni okvir Pisnik rabi uglavnom na razini prigodne asocijacije. Primjerice, za artikuliranje intenziteta osobnog udesa, kad govori o razmjerima rasula vlastite obitelji, poslužila je usporedba s propašću Troje: „Veliko i malo našega pokoja/ sve se je propalo, sva naša ogoja./Žalosti ni broja koja nas dopade,/ kakono i Troja slafni grad ki pade“ (Vila, 1, 23, 301-304).

$\mathrm{U}$ korpusu refleksija, fraza, poslovica u epizodama koje rabe mitske slike zamjetno su zastupljeni figuralni i retorički postupci, poput tropa (alegorija), te epskog postupka

16 Vila je mitološko biće sa svim slojevima značenja koje uobičajeno podrazumijeva književnost epskih, pastoralnih i lirskih vrsta i podvrsta. Odgonetajući njezin identitet pri prvom susretu Pisnik je kontekstualizira društvom znamenitih mitoloških ljepotica: „Zlamen mi jur daju bili vrat i lišca/ da si ti pri naju Dijana divica,/al' Venus božica, al' mudra Palade,/ al' vela kraljica ugarske posade“ (Vila, 1, 20,185-188). Njezino je podrijetlo pak istovjetno slovinskomu. Kao što je Nino Nembrotov sin (hebrejski mit o Babilonu) i ona je iz Nembrotova plemena, mada neštovana dovoljno od svojih. Saražinke, Grkinje i Latinke ravnopravno stoje, a Slovinka zaslužuje istu čast koja joj je uskraćena: „Ni moja lipota od mojih dvorena,/ od krvi Nembrota ja buduć stvorena“ (Vila, 7, 114, 941-942). O slojevitosti njezine uloge u spjevu iscrpno je pisao Svetozar Petrović: „Dok je kod Zoranića vila, zapravo, češće zaštitnica i pomoćnica - koja će pjesnika provesti teškim putem ili prenijeti na putu neprohodnom - a uz to samo koji put „savjetnica“ tj. biće koje će pjesniku dati poneku pouku ili mu objasniti poneku od stvari što ih susretnu, kod Barakovića je ona jedan od ključnih i po značenju samostalnih likova spjeva, na njena se usta pojavljuje pisniku vizija narodne povijesti i povijesti rodnoga grada, kroz nju se implicite izriče jedan ideal slovjenske poezije, i lomeći se s njom, pisnik se osjeća zakinutim za nadahnuće jedne vrste. Po svojoj funkciji u spjevu, dakle, Barakovićeva je Vila muza epske naracije (ona koju Eneida poziva u pomoć kad treba govoriti o mitološkoj prethistoriji i nevoljama Enejinim ili o historiji Lacije, ili kad treba navesti junake i vojske suočene u bitki, isp. Aeneis I, 8; VII, 37, 641, isp. također Curtius 1956: 282; u njenom je liku, međutim, izrazita i funkcija zatočnika, patrona poezije, kakva se ističe kod muze didaktičkog pjesništva. A što je najvažnije, i što Barakovića od njegova uzora konačno i potpuno odvaja, vila u Barakovićevu spjevu nije jednostavno saveznik koji se u nuždi zaziva u pomoć, nije sredstvo komponiranja ni navika stila, nego predmet - u jednoj interpretaciji Vile Slovinke moglo bi se reći: glavni predmet - spjeva (1968: 201). Svakako, mitski prostor kojim se prožima i izjednačuje poetski, a vilina prisutnost ga obilježava, podrazumijeva cjelovitost i neodvojivost mitova različitih naroda koji se prožimaju i lako se premještaju u izjednačavanju. Tako se, primjerice, vilinskoga kola ne bi sramio ni sam Apolon. Njegova je pojava prezentirana uobičajenim općim mjestom: „skupismo tad kolo hitrima čudesi,/ kim ne bi Apolo sraman na nebesi,/ kad svojih kolesi uz nebo potoči,/ ter doli do tlesi nam svitlost uzroči“ (Vila, 4, 66, 18-192). 
kataloga ili pak različitih asocijacija. Poput, na primjer, figura u katalogu junaka trojanskoga rata u službi prozopografije Otaviana, strica Anjela Justinijanovića: „Ajace, Ulise i tvrdi Akile,/ i ča Omer piše grčke vojske sile,/ ne bi vridne bile prid ovoga stati,/ nit bi lasno smile da ga mogu znati;/ nazad te mu stati trojanska gospoda/ kim Ekuba mati prvo bitje poda,/Etor slafna roda sin Prijama kralja,/ ki grčkoga ploda dobar dil povalja,/ mnju da ga ostaflja glasom i nadhodi;/ Ateni zabaflja, Kretu mimohodi“ (Vila, 8, 247-256). U istom kataloškom registru stoje i umni historičari i filozofi: „Vas razum Plinija ki na svit ostavi/ i Tita Livija nauk od naravi,/ svaki da bi slavi‘ svitlosti ovoga/ veće bi ostavi' nego bi zreć moga': da bi Platun mnoga pisma k njemu obrati',/ Arištotil svoga da bi ne zakrati““ (Vila, 8, 259-264). I druge povijesne istaknute ličnosti su u katalogu: „i Kraso s pinezi i z blagom da pride,/ [...] da bi ga objaha“ srditi Atila/ [...] Bruta i Kamila plemenstvom se diči“ (Vila, 277-289).

Osim toga, u prvom dijelu Vile Slovinke i niz panegiričkih pjesama koje ne govore o mitskom postanju grada (uvodna posvetna pjesma, pohvale Zadru, njegovim stanovnicima i strateškoj važnosti grada te pohvala pjesnikovoj obitelji) pripadaju istom diskurzu. Vila Satažina, na primjer, uvodi čitatelja u predstavljanje dobroga glasa suvremenoga Zadra invokacijom mitske zore: „gdi zora zhojuje, pokle se dili mrak,/ [...] Titona čestita za muža, gdi poja,/ nigdar ga ni sita, pokle ga posvoja“ (Vila, 6, 68, 19, 23-24). Zadar od neprijateljskog prilaza sa zapadne morske strane čuva Neptun: „Nitkor u nj ulazi od strane zapada,/ Neptun ga tuj pazi, pasući sva stada“ (Vila, 6, 74, 241-242). Snagu zadarskih lumbardi demonstriraju Jazonovi bivoli: „a gdi je skučen zid, svak biži otoli,/ jer zmaji bljuju jid, slekši se na koli;/ već nego bivoli, kih Jažon upreže“ (Vila, 6/74, 259-261). U sličan se kontekst uvodi i usporedba s Plutonom (Vila, 6, 75, 271). A Grad čuva veliki kapetan kao Hektor (Vila, 6, 77, 364). U nešto drukčijem kontekstu, topika savršene ljepote Zadranki izgrađena je na vezi sa kreacijom savršenih tvoraca od grčkih bogova do umjetnika: „Zeuši ni Apel, Pigmalijon stari,/ Fidija, Prašitel, al“ novi pismari,/ knjižnici, nabdari, premda bi svi htili, pismeni slogari ki su sad i bili,/ ne bi moć imili, ni pamet toliku,/ niti bi umili sličit njih priliku./ Mi ke smo sad vile krasne i pokojne,/ ne bismo jim bile služiti dostojne." (Vila, 6, 86, 665-672).

Interpretacija antičkog mita u Vili Slovinki, koja zamjetno participira u kreiranju osnovne priče u prvom dijelu spjeva i u kreiranju pseudopovijesnih ideja, slično je tretirana i u drugim književnim djelima u ranom novom vijeku, s tim da je, zahvaljujući pastoralnom žanrovskom okviru i odmaku od antičkog mita prema inveniranju slavenske mitologije sukladno sekundarnom žanru metamorfoze, u ponešto povlaštenijoj poziciji od tematike i motivike slične mitske provenijencije u epici, na primjer, jer nije nužno otvoreno kristijanizirana. ${ }^{17}$

17 Doduše, u pogledu (ne)zastupljenosti antičkog mita u motivici zanimljivima se pokazuju, primjerice, Vetranovićev Piligrin i Hektorovićevo Ribanje i ribarsko prigovaranje - narativna djela sa znatnim vijatorskim motivskim slojem u osnovnoj priči. Već i osnovni uvid u sadržaj svjedoči o Vetranovićevoj sklonosti ka uvođenju mitskih motiva u alegorijsko djelo i Hektorovićevoj izrazitoj nesklonosti utkivanju antičkog mita u priču na bilo kojoj razini. Štoviše, jedino spominjanje „mudrog Fitagore“ eksplicitno svjedoči o apologiji antike, no već na razini stila razabire se sklonost upotrebi vrlo plastičnih opisa tipičnih za antičku narativnu književnost. Da se ne radi o slučajnosti potvrđuje i Hektorovićev izbor za prijevod iz Ovidijevih Metamorfoza samo ulomka koji govori o pogubnosti ljubavi, istrgnuta iz cjeline različitih mitskih ljubavi. Minus 
U drugom se dijelu spjeva mijenja i zastupljenost i status mitske motivike i figuralnosti u priči, na retoričkoj i na stilskoj razini, gdje eksplicitno naglašeniji postaje kršćanski aspekt događanja i priče. ${ }^{18}$ Podudara se ta promjena i sa žanrovskim mijenama u drugom dijelu: od panegirika Zadru spjev se transformira u peregrinacijski narativ u kojem Pisnik i njegov novi sugovornik Poklisar/Osin, koji supstituira odbjeglu kazivačicu Vilu, kroz pripovijedanje o suvremenicima i o susretima s fikcionalnim bićima, lutanjima i događajima govori o grijehu, ispaštanju, trapljenju i vrlinama. U takvoj je temi, kojom se prema Pisnikovoj nagovijesti trebao proslaviti i Šibenik, nakon što je uobičajenim formama panegirika proslavljen Zadar, mitska ikonografija svoj prostor izgubila, pronašla ga je samo u prizorima pakla u 12. pjevanju. Razlaz Pisnika sa svojom muzom u burnoj prepirci posreduje čitatelju i poetičke razloge minorizacije mitskih tema, kao svojevrstan implicitni minus postupak. To se, naravno, odnosi na nedostatak pričica i motiva te kataloga, a ne na kratke asocijacije koje počivaju na mitskim sličicama i nalazimo ih povremeno na frazeološkoj i gnomskoj razini, u metaforičkim i poredbenim topoima nastalim od reduciranih mitskih anegdota, jer ih nalazimo i u drugom dijelu. Često se Baraković u frazeologiji oslanja na rasprostranjene izreke, primjerice kad Pisnik opisuje svoju potrebu da pjesništvom ugodi Zadru rabi popularnu metaforu trpljenja: „Rad želje velike zgodit mu ku imam,/jak Tantal kraj rike od želje umiram“ (Vila, 7/109, 771-772). U istovjetnoj se ulozi rabi i metaforička slika mladoga Ikara: „u meni da stara prišca se ne zgodi/mladoga Ikara ki umri u vodi (Vila, 7, 109, 777-778), a želju za slavom epika simbolizira Klio: „Zaludo s tugami želim steć onu slast,/ gdi Klio z drugami uživa svoju čast“ (Vila, 7, 109, 799-780). Metaforički se označava pjesništvo i u Odgovoru prijatelju Josipu Ivetiću na posvetnu pjesmu: „s tobom sve kad vide sestre Aganipe“ (Vila, 235, 2). Ili pak, za opis kolovoške vrućine poslužila je metafora grčkog božanstva i astrološkog znaka: „kad kosu zlaćenu Apolo zlatoglaf/ dopusti zlamenu kogano druži laf“ (Vila, 170, 12, 41-42). Ponovno se služi sličnom slikom metafore razdanjivanja: „Zlatnima kosami noćnima razdili./ Tada se zabili nikoko moru vrh“ (Vila, 173, 12, 145-148). ${ }^{19}$

Već u vituperaciji u kojoj se prenaglašeno hvali junaštvo uglednih zadarskih obitelji u osmom pjevanju, nema očekivanog kataloga mitskih likova ${ }^{20}$ prispodobivih, primjerice,

postupak pokazuje određeni stav prema mitskim motivima u književnosti. U kolikoj je to mjeri povezano s kršćanskim svjetonazorom u djelu, zasebna je tema.

18 Poslije razlaza s Vilom otpočinje drukčiji slijed događanja u kojima se aktualizira Pisnikova „stvarnost“: susret s Poklisarom bega hlivanjskoga u okolici Šibenika nastavlja se vijestima o piru uglednika u Zadru i bugaršticom o smrti Pisnikova brata i nećaka. Slijedi susret i vjerski razgovor s pustinjakom na brdu ponad grada, ispovijest o neuspjelom snubljenju djevojke, trapljenje i lutanje divljinom, potom kratkotrajan spas u Trogiru ali i daljnji nemir: bijeg i lutanje morem, što završava pred paklenim otvorom na Vulkanu (Liparima) u razgovoru sa sjenom negdašnjeg Poklisara; naposljetku, povratak u Šibenik brodom sirijskih trgovaca, gdje čitanje knjige o podvizima šibenskog junaka Frane Strižoevića prekida pogrebni ispraćaj tog istog junaka.

19 No, gnomičnosti teksta nije izvorište samo antički mit, potpomognuta je, primjerice, biblijskom metaforikom: „da bude Salamun u meni prominjen,/ kriposti svake pun, prez blaga ni scinjen“ (Vila, 7, 109 793794). Ista biblijska figura mudrosti još je jednom dio frazeološke topike: „da bi pisma nova sva od njega pela,/ i Salamunova mnju da bi se smela“" (Vila, 267-268).

20 Redukcija mitskih elemenata ne podrazumijeva, na primjer, opće mjesto ženske ljepote svedene u, inače nekonvencionalna panegiričara, Poklisara bega Hlivanjskoga na pohvalu Darije Macarelić, zaručnice Federika 
konvencijama u panegiriku Justinijanoviću. Izostanak diskurza obrazovanih, koji je redovito u funkciji humanističke legitimacije, posljedica je i drukčijeg etosa novog kazivača koji registrom pripovjednog iskaza neprikladnim hvalospjevu aristokracije preoblikuje panegirik u vituperaciju i ironiju. ${ }^{21}$

Nakon nestanka Vile naratorice mitskih/pseudopovijesnih priča, nove priče ne podrazumijevaju nužno i mitsko-povijesni stilsko-figuralni kompleks. Ikonografija fikcionalnog prostora kakva se nalazi u prikazu raja u 9. pjevanju, nije antičke provenijencije, nego pripada topici kršćanskoga prostora - s plastično prikazanim rajskim nebom s Djevicom Luzaricom, okruženom kršćanskim svecima, ${ }^{22}$ koja Pisnika pokušava podignuti u raj pruženom krunicom. Omiljena posttridentska ikonografija i posve eksplicitno ustupa mjesto mitskoj priči. Semantička slojevitost tog prizora razabire se ponajprije na razini lika kao signala poetičke smjene u kojoj Djevica postaje nova muza umjesto odbjegle Vile. Potom, na razini priče: intimistička zgoda Pisnika patnika, izopćenika iz rodnog Zadra i k tome nevoljna i grješna zaljubljenika, posjeduje u toj epizodi nagovijest $u$ iskupljenje krunicom koju će ponoviti i u podzemlju Poklisarov Osin. Gubitak Vile u drugom dijelu spjeva znači raspodjelu njezinih funkcija: duhovna voditeljica i nova muza postaje Marija Luzarica, a izvjestitelj o suvremenim zbivanjima iz Zadra Poklisar, dok njegova sjena, Osin, postaje savjetnik i vodič u podzemnom svijetu. Dakle, Poklisar i Osin predstavljaju varljivost i grješnost ovoga svijeta i ispaštanje u čistilištu.

Ikonografija Barakovićevih nebesa, s djevicom kao ključnim utočištem grješnika, proizvod je tridentskih (Koncil se održavao 1545-1565) naputaka o važnoj ulozi književnosti i, nadasve, o umjetnosti u procesima osnaživanja vjere. Posebno mjesto u osnaživanju pobožnosti zauzimalo je čašćenje svetaca i svetih slika što je, između ostalog, i znak otpora i ignoriranja ikonoklazma luterana. ${ }^{23} \mathrm{~K}$ tome, poduzeta je korjenita obnova podrazumijevala upute (professio fidei Tridentina) za osobnu pobožnost, primjerice, odredbe o svakidašnjem moljenjenju časoslova pape Pija IV. ${ }^{24}$

Grizogona na usporedbu s Helenom: „Nije čudo kako slišu,/ da bi Troja razorena,/ pokle uzrok njoj bi žena,,/ kako stari pisci pišu,//Grkinjica gospodična,/ rad ke Troje ni ostalo;/ učiniše Grci malo,/ ako biše ovoj slična“ (Vila, 8, 123, 251-258).

21 MRDEŽA ANTONINA, Divna: Panegirik ili satira u Vili Slovinki Jurja Barakovića? - muka citatelja s povijesne distance. In: Satire und Komik in der bosnisch-herzegowinischen, kroatischen, montenegrinischen und serbischen Literatur. Ur. Renate Hansen Kokoruš - Darko Lukić - Boris Senker, Kovač. Hamburg, 2018, s. 13-32.

22 PRIJATELJ-PAVIČIĆ, Ivana: Kiparska i slikarska umjetnička baština bratovština u Dalmaciji između XIV. $i$ XIX. st. Croatica Christiana Periodica, 40, 1997, s. 39-53.

23 CVETNIĆ, Sanja: Ikonografija nakon Tridentskog sabora i hrvatska likovna baština. Zagreb: FF press, 2007.

24 Poslije Tridentskog koncila (1545-1563), već i prije osnivanja Congregatio de propaganda fide (1622), a osobito pod vodstvom kardinalske Kongregacije Crkva je ne samo nesmiljeno obračunala s protivnicima nego i povela snažnu i dugotrajnu bitku za katoličanstvo na svim razinama i brojnim sredstvima, uključujući unutarnje konsolidiranje redova strožim pravilima ponašanja, a prema vjernicima tiskanjem teološke literature, širenjem vjere propovijedanjem, zagovaranjem umjetnosti koja počiva na misticizmu s naglašenim emocijama i temama o grijehu i oprostu, katehizacijom i misionarskim djelovanjem diljem svijeta nakon čijih velikih uspjeha se govori se o katoličanstvu kao univerzalnoj crkvi. O tim aktivnostima postoji brojna literatura (usp. npr. GUILDAY, Peter: The Sacred Congregation de Propaganda fide (1622-1922). Catholic Historical Review, 6, 4, s. 478-494, Catholic University of America Press, 1921). O dubini i opsegu promjena na prostoru Dalmacije svjedoči već prva papinska vizitacija 1579. 
Egzemplar književnih postupaka koji počivaju na upotrebi mitske priče smanjuje se i u prozopografiji, što demonstrira pohvala Rafaeli Ivetić, uglednoj glavarici samostana sv. Spasa, u kojoj nema traga katalogu, uobičajenom u predstavljanju lika u epici. Osobine poput ljepote, hrabrosti i mudrosti zamijenjene su redovničkom vrlinom kreposti uspoređenom jedino sa sv. Klarom: „druga bi se Klara svitu objavila;/ ona je imila tu milost od boga,/ zlamenja činila i čudesa mnoga,/ a ovu ni moga pridobit grihom svit,/ zač uhrani svoga čistoga difstva svit.“ (Vila, 10, 151, 280-284). Štoviše, mitske figuralnosti svostvene poredbama u mitskoj topici panegirika nema ni u pohvali viteškoj figuri junaka - Šibenčanina Frane Strižoevića. Njegovu veličinu prikazuje opis pogrebnog ispraćaja čime se i kategorija junaštva stavlja u kontekst ideje o prolaznosti.

U novom je tematskom kompleksu koji obuhvaća epizode iz Pisnikova života u Šibeniku i susrete u lutanjima kopnom do Trogira, a potom i bijeg morem do Lipara ${ }^{25}$, samo fikcionalni prostor čistilišta i pakla na otoku Bulkanu postao temom prikladnom za cjelovitu implementaciju mitske priče (soteriološki mit). U tu je svrhu posuđena topika prostora Hada/Tartara i pratećeg mu osoblja kakve, inače, sadrži klasična lektira poput Eneide, ${ }^{26}$ i srednjovjekovnih vrsta, poglavito Danteova Pakla ${ }^{27}$ i eshatoloških vizija.

Baraković, doduše, uvodi preinake u odnosu na Eneidu. ${ }^{28}$ Međutim, glavnina toponima i stanovnika su predstavljeni čitatelju: umjesto Vergilijeva Aheronta „Tuj virom paklenim Letefka izvire“ (Vila, 192, 12, 878); „Karonta čekaju dokle jih pribrodi“ (Vila, 193, 12, 885); sedam putova koji vode do rijeke za sedam vrsta grijeha od povratka griješnika čuva poznata straža „Minošan grdak, star, kusorep, glavorog/na vrati jest vratar držeć broj i razlog“ (Vila, 193, 12, 904-905); „Ne moj se čuditi, ako sam tač ružan,/ hti pravo suditi, je li duh moj tužan/ s onimi pridružan kih vlada kralj Plutan“ (Vila, 185,

25 Fikcionalni prostor toponimijom aludira na Lipare, i još neke vulkane poput Etne (Vila, 192, 12, 846), uz koje se vezuju i popularne priče o mitskom prostoru. U fikcionalnom kontekstu realni geografski vulkanski toponimi sugeriraju čitatelju vjerodostojnost da bi prihvatio sedam paklenih vrata kao činjenicu: „Vulkan je prva zjat, a druga Lipari,/ Iškja put tretih vrat, a Štrombol četari,/ Mogibel gdi vari sumporom smrdna smet/ [...] a Pocuol smradan šest, a sedma ostaje/ gdi Erkul zarva dva čudna zlamena,/ dva stupa, ne drva, neg tvrda kamena/ [...] Misto je to Vulkan paklen vrh srid mora,/ ali ti reć Bulkan, otok je ni gora" (Vila, 211, 12, 1521-1536).

26 Da je Barakovićev motiv pakla literarne provenijencije, kao i slični prizori pakla u Planinama, a što podrazumijeva oblikovanje prostora prema ustrojstvu podzemnog svijeta različitih antičkih mitova prisutnih u klasičnoj epici, u prvom redu Vergilijoj Eneidi, a potom Danteovu Paklu, odavno je uočeno u hrvatskoj povijesti književnosti. Prva važnija zapažanja u književnoj povijesti, počevši od opaski većeg broja istraživača (Bogdanović (1900), Cronia (1921), ponajviše V. Dukat (1932) i Petravić (1935)) koje su preuzimane u povijesti književnosti do novijega vremena, donosi u kritičkom pregledu S. Petrović u opširnoj bilješci u članku Problem soneta u starijem hrvatskom pjesništuu. Op. cit., s. 189-193.

27 Opis muka u Barakovićevu paklu sličniji je grozotama srednjovjekovnih vizija na koje se ugleda i Dante (primjerice, ispaštanja i kazne u Pavlovoj apokalipsi) nego Eneidi. Određene podudarnosti s Danteom su uočljive (primjerice, tri furije su sličnije Danteovu prikazu nego Vergilijevu, ali mogao ih je Baraković preuzeti i iz lirike svoga vremena, primjerice Saba Bobaljevića Glušca (PETROVIĆ, Svetozar: Op. cit., 1968, s. 193).

28 Na primjer, tri furije smješta u Tartar, na vratima stražari Kerber, a intervenira i u opis čudovišta uvodeći, primjerice, sedmoglavu hidru, koja podsjeća na Zoranićevu „Kimeru, zvir sedmoglavu“, ali i na grb Sforze Palavicina, graditelja zidina Zadra koji je dao nemilosrdno uništiti čitav jedan kvart da bi na tom mjestu izgradio dvostruki niz zidina na jugoistočnoj strani grada, opisan u trećem pjevanju (PETROVIĆ, Svetozar: Op. cit., 1968, s. 190). 
616-618); na Elizejskoj poljani su smješteni ljubavnici, a imenom se spominju oni koji su uspjeli udobrovoljiti Kraljicu zlatnim listom s „duba zlatolista“, „Te straže paklene pustiše Orfeja/ rad želje ljubene i smina Težeja,/ Poluce, Eneja, Erkole mogući“ (Vila, 199, 12, 1096-1098); na trećem ulazu za pravi pakao (vječne muke) čuvari su „Gorgona, krastaf slif, Jerion, Erilo, a prostor je okružen 9 puta rijekom Erebom; tu stoluje „Radomant“ Plutonov drugi brat, a služe mu: „Aleto, Tešifon, Mejera“ (Vila, 200, 12, 1125). U paklu su smješteni svi teži griješnici uz „žigante staroga vrimena“, poput Titana Prometeja; tri „vojvode“ su „kraljevi vijećnici“ i kontroliraju kažnjavanje tri najteža grijeha (oholost, lakomost, blud), prvi je vojvoda Lucifer zadužen za ohole, drugi je Mamon koji se brine za lakomce, a treći Asmoden za bludnike. ${ }^{29}$

Epizoda s paklom nije samo emblematski dio peregrinacijskog spjeva u ulozi didaktične opomene za grješne, čemu mitski personal pridonosi svojom zastrašujućom pojavnošću i aktivnostima. U sadržajnom sklopu spjeva pakao je ključno mjesto, važno za razumijevanje slojevitih odnosa Pisnika i svijeta u kojem obitava i s kojim je u sukobu, što, u prvom redu, posreduje Pisnikove osobne obračune s bivšim sugrađanima, ali i s vlastitim grijehom. Primjerice, mitski je Vulkan zadužen za ognjena željezna mučila kakve nosi despot Đurađ Branković, simbol grijeha prijevare i izdaje, a već je većina književnih povjesničara zapazila da on nije slučajno detaljno prezentirani grješnik, štoviše on je jedini, zato što je u sadržajnom sklopu relevantno da se nauku izdaje obučio baš u Zadru, gradu što: „krunu jur vazima ku nosi grad Babel,/ vidjen bi očima, da bude živ Apel“ (Vila, 209, 12, 1444-1445). U tom je kontekstu kažnjavanja moćnih, a neharnih i razmetnih, razumljivo da je čitatelj danteovski upozoren na osuđene velikodostojnike neharne prema podložnima: „ki bihu neharni, slugam ki dvoriše, /služeći za mani na službi umriše“.

Srednjovjekovnoj pak podjeli donjega svijeta Baraković duguje smještanje čistilišta u svojevrsno predvorje pakla, što se još uvijek nalazi i u ranonovovjekovnoj teološkoj literaturi, gdje se Purgatorij: „također [...] zove Pakao, za bit pod zemljom, i toliko blizu pravoga Pakla“. ${ }^{30}$ Dakle, nisu u Barakovićevoj viziji pakla zanimljivi samo „topografija, imena i opis personala i gostiju“31 već i funkcija diobe prostora. Prvim dvama dijelovima, čistilištem i „Eližijskim poljem“ vlada Pluton, a trećim Radomantovo kraljevstvo osuđenih „na vječne muke“, a podjela omogućuje Poklisarovu Osinu (Pisnikovu svojevrsnom vodiču) dobru informiranost o pridošlicama u pakao i razgovore s Jurjem Smiderskim sa sigurne udaljenosti, a što pak objašnjava i zašto se prostor pakla u tom segmentu razlikuje od prostornog rasporeda u Paklu klasičnih autora. ${ }^{32}$ No, prostor čistilišta sluti Pisnik i kao vlastito zagrobno odredište, iako mu Osin nagoviješta i mogućnost iskupljenja od muka nakon trapljenja koje je obavio na zemlji. Sugerira time Pisnik da je njegovo lutanje i mučenje ovozemaljska muka kojom zaslužuje iskupljenje.

29 BARAKOVIĆ, Juraj: Djela. Priredili P. Budmani - M. Valjavac. Stari pisci hrvatski. Zagreb: JAZU, 1889, s. 203.

30 ORBINI, Mavro: Kraljevstvo Slavena. Prev. Snježana Husić; prir. Franjo Šanjek. Zagreb: Golden marketing, 1999, s. 103-104.

31 PETROVIĆ, Svetozar: Op. cit., s. 190.

32 Ibidem. 
Posve su razumljive teme trapljenja, ispaštanja i oprosta u Vili Slovinki u kontekstu nadolazećeg vremena njihove popularizacije u književnosti 17. stoljeća, što je posljedica posttridentskog njihova poticanja u skladu s idejom o važnosti uloge umjetnosti i književnosti u konsolidaciji katoličanstva. Već samo neki najistaknutiji, naslovi čiji sadržaji obuhvaćaju temu Mandalijene pokornice, kojoj su se posvetili važni barokni pisci Ivan Bunić Vučić i Ignjat Đorđić, ili pak Suze sina razmetnoga Ivana Gundulića, dovoljno svjedoče o revitalizaciji jednog posebnog aspekta pobožnosti koji je postao vrlo popularan u književnosti 17. stoljeća, a zadržao se i stoljeće poslije.

Upravo je koncilska aktivnost potakla temu čistilišta, čija je važnost dodatno porasta potrebom odupiranja luteranskoj sumnji u smisao njegova postojanja. Sudeći prema broju stihova kojima se tema čistilišta i pakla prezentira u Vili, i prema ključnoj ulozi teme u razumijevanju odnosa Pisnika i Zadrana, Baraković se književnim „tumačenjem posljednjih stvari“ stavio u red ozbiljnih službenika koji zagovaraju ideje Koncila. Problematika prevrednovanja stupnjevanja griješnosti - težine ljubavnih grijeha naspram laži, oholosti i izdaje - u sloju osobnih Pisnikovih obračuna i životne priče samo su refleks ideja o novoj pobožnosti.

Doduše, nove su se ideje nadovezale na ideje devotio moderna ${ }^{33}$, katoličkog pokreta raširenog Europom koji je zahvatio hrvatske krajeve i prije tridentskog koncila, a koje su zasigurno pridonijele i izravnoj kristijanizaciji mitskih tema i motiva. Doduše, mit nikad nije bio kamenom spoticanja u određenju svete priče u našoj književnosti, pa ni onda kad su se njime na tematskoj razini djela zaokupljala u nešto većoj mjeri. Kako je mitologija uglavnom egzistirala kao alegorija i metafora u književnosti, kao i u umjetnosti gdje je izazivala brojne prijepore u crkvenim krugovima kasne renesanse, s današnje se distance čini nepotrebnom revnost u postridentskoj propagandi oko pojačane kontrole mitske priče u književnosti.

Mit etnogeneze duže će se zadržati u književnosti pa i u povijesti, unatoč znanstveno profiliranim historiografskim pogledima u knjizi povjesničara Ivana Lucića $O$ Kraljevstvu Dalmacije i Hrvatske iz 1666., a kristijanizirane mitske teme poput ljubavi mitskih božanstava i podviga bogova i heroja nastanit će se posebice u melodrami i libretističkoj drami.

Značajno se u književnosti zadržao i soteriološki mit, a u okviru motiva grčko-rimsko-kršćanskoga pakla karakterizirat će epiku i poslije Barakovića, Primjerice, u vodećem posttridentskom epu hrvatske književnosti Osmanu Ivana Gundulića postridentsko će postupanje s mitskim paklom na razini fabule dosegnuti svoj vrhunac u svjetlu teološkog tumačenja pakla kao mjesta koje upravlja širenjem zla u stvarnom svijetu. I Barakovićev blizak prijatelj Ivan Tonko Mrnavić u drami Osmanščica značajno mjesto dao je paklenim silama zla i njihovu upravljanju političkim procesima u Osmanskom carstvu.

U Barakovićevu je spjevu pakao mjesto ne samo propagiranoga konačnog obračuna, nego i prostor za osobnu osvetu, ali i mjesto koje odražava njegovu postridentsku revnost zahvaljujući kojoj i sve inovjerce nije propustio smjestiti u pakao.

33 Među programatskim teološkim spisima toga pokreta ističe se Nasljeduj Krista (De imitatione Christi) Tome Kempenskoga. 


\section{Literatura}

\section{I.}

BARAKOVIĆ, Juraj: Vila Slovinka Jurja Barakovića Zadranina u četari varsti petja složena, ča jest u pismi skupne, u osmoredke, u zučnopojke i u poluredke. Antonio Turini, Venecija, 1614.

BARAKOVIĆ, Juraj: Djela. Priredili P. Budmani - M. Valjavac. Stari pisci hrvatski. Zagreb: JAZU, 1889.

II.

BAHTIN, Mihail: Estetika jezičkog stvaralaštva. prev. Mirjana Grbić. Novi Sad: Izdavačka knjižarnica Zorana Stojanovića, 2013.

BELAJ, Vitomir: Hod kroz godinu. Pokušaj rekonstrukcije prahrvatskoga mitskoga svjetonazora. Zagreb: Golden marketing, 1998; 2. izmjenjeno i dopunjeno izd., Zagreb, 2007.

BELAJ, Vitomir: Nacrt za proučavanje hrvatskog baroknog bajoslovlja. Radovi hrvatskog društva folklorista, 1995, 2-3.

CVETNIĆ, Sanja: Ikonografija nakon Tridentskog sabora i hrvatska likovna baština. Zagreb: FF press, 2007.

GRMAČA, Dolores: Nevolje s tijelom. Alegorija putovanja od Bunića do Barakovića. Zagreb: Matica hrvatska, 2015.

GUILDAY, Peter: The Sacred Congregation de Propaganda fide (1622-1922). Catholic Historical Review, 6, 4, s. 478-494, Catholic University of America Press, 1921.

ELIADE, Mircea: Mit i zbilja. Prev. Mirna Cvitan - Ljerka Mifka. Zagreb: Matica Hrvatska, 1970.

KENNEDY, William J.: Jacopo Sannazaro and the uses of Pastoral. Hanover - London: University Press of New England, 1983.

KOMBOL, Mihovil: Poviest hrvatske književnosti do narodnog preporoda. Zagreb: Matica hrvatska, 1945.

KRAVAR, Zoran: Das Barock in der kroatischen Literatur. Köln - Weimar - Wien: Böhlau, 1991.

MEDINI, Milorad: Povijest hrvatske književnosti u Dalmaciji i Dubrovniku. I knjiga. XVI. Stoljeće. Zagreb: Matica hrvatska, 1902.

MONTROSE, Louis Adrian: Proučavanje renesanse: poetika i politika kulture. In: Poetika renesansne kulture: novi historizam. Ur. David Šporer. Zagreb: Disput, 2007, s. 53-78.

MRDEŽA ANTONINA, Divna: Žanrovski status teksta. In: Vila, Pisnik i čatnici. Zbornik radova sa znanstvenog skupa „,Vila Slovinka‘ Jurja Barakovića (1614-2014)“. Ur. Divna Mrdeža Antonina. Zadar: Sveučilište u Zadru, u suradnji s HAZU i Filozofskim fakultetom u Zagrebu, 2017, s. 213-238.

MRDEŽA ANTONINA, Divna: Panegirik ili satira u Vili Slovinki Jurja Barakovića? - muka čitatelja s povijesne distance. In: Satire und Komik in der bosnisch-herzegowinischen, kroatischen, montenegrinischen und serbischen Literatur. Ur. Renate Hansen Kokoruš - Darko Lukić - Boris Senker, Kovač, Hamburg, 2018, s. 13-32.

NIXON, C. E. V. - SAYLOR RODGERS, Barbara: In praise of later Roman emperors: „The panegirici latini", Introduction, translation and historical commentary, with the latin text of $R$. A. B. Mynors. University of California Press, 1994. 
ORBINI, Mavro: Kraljevstvo Slavena. Prev. Snježana Husić; prir. Franjo Šanjek. Zagreb: Golden marketing, 1999.

PAVLIČIĆ, Pavao: Vila Slovinka. In: Epika Granice. Zagreb: Matica hrvatska, 2007, s. 109-163.

PETROVIĆ, Svetozar: Problem soneta u starijoj hrvatskoj književnosti (Oblik i smisao). Rad JAZU, 350, 1968, s. 5-303.

PRICE, Glanville: Romance studies in Great Britain. In: Trends in Romance Linguistics and Philology. Vol. 4: National and Regional Trends in Romance Linguistics and Philology. Ur. Rebecca Posner i dr. The Hague - Paris - New York: Mounton Publishers, 1982, s. 127-171.

PRIJATELJ-PAVIČIĆ, Ivana: Kiparska i slikarska umjetnička baština bratovština u Dalmaciji između XIV. $i$ XIX. st. Croatica Christiana Periodica 40, 1997, s. 39-53.

ŠVELEC, Franjo: O kompozicijskim osobitostima Vile Slovinke. In: Po stazi netlačeni. Split: Čakavski sabor, 1977, s. 195-212.

ZORANIĆ, Petar: Planine. Prijevod i komentari Marko Grčić. Zagreb: Grafički zavod Hrvatske, 1988.

prof. dr. dc. Divna Mrdeža Antonina

Sveučilište u Zadru

Odsjek za kroatistiku i slavistiku

Obala kralja P. Krešimira IV 2, 23000 Zadar, Chorvatsko

divna.antonina@gmail.com

Toto dílo Ize užít v souladu s licenčními podmínkami Creative Commons BY-SA 4.0 International (https://creativecommons.org/licenses/by-sa/4.0/legalcode). Uvedené se nevztahuje na díla či prvky (např. obrazovou či fotografickou dokumentaci), které jsou v díle užity na základě smluvní licence nebo výjimky či omezení příslušných práv. 
